\title{
PENGARUH PEMBERIAN IKAN TERI (Engraulis encrasicolus) PADA MEMORI SPASIAL TIKUS SPRAGUE DAWLEY USIA SATU BULAN
}

\author{
Siska Indah Septiana, Niken Puruhita*) \\ Program Studi Ilmu Gizi Fakultas Kedokteran Universitas Diponegoro \\ Jl.Dr.Sutomo No.18, Semarang, Telp (024) 8453708, Email : gizifk@ undip.ac.id
}

\begin{abstract}
Background: Spatial memory is a part of cognitive function which vitally influences life. Black Sea Anchovy is and oily fish which contains high Omega-3 fatty acid in a form of Docosahexaenoic Acid (DHA) and Eicosapentaenoic Acid (EPA). Omega-3 fatty acids has been known related to synaptic plasticity that mantain hippocampus performance which have a role on memory and learning. This study conducted to observe the effect of dietary black sea anchovy in spatial memory spatial acquisition in one month-old Sprague dawley.

Methode: True experimental with post test only with control group design using 21 Sprague dawley rats which were randomly divided into three gropus; control, anchovy, and fish oil. A food package of $1.5 \mathrm{~g}$ anchovy or $167 \mathrm{mg}$ fish oil for $200 \mathrm{gr}$ weight that mixed in their fed for 14 days. Spatial acquisition test conducted with Morris water maze test to measure both both spatial observation performance and spatial biases level. Data gathered Data statistically analyzed non-parametric test Wilcoxon and Multivariate ANOVA then continued with LSD.

Result: A significant different shown at hidden platform test, there is a decrease percentage was observed at dietary anchovy group (67.89\%) compared with control group (21.53\%) but no significant different appears at fish oil groups. There was also a different at spatial bises level between three groups but failed to be proved stastically.

Conclusion: Dietary black sea anchovy improved spatial observation performance but no effect on spatial biases at one month-old Sprague dawley.
\end{abstract}

Keywords : Engraulis encrasicolus; spatial memory; hippocampus; cognitif; morris water maze

\section{ABSTRAK}

Latar Belakang: Memori spasial merupakan bagian dari kognitif yang berperan penting dalam kehidupan. Ikan teri (Engraulis encrasicolus) merupakan salah satu jenis oily fish yang memiliki kandungan omega-3 dalam bentuk EPA dan DHA yang tinggi. Asam lemak omega-3 berperan pada tingkat aktivitas plastistas sinaptik yang mengatur fungsi hipokampus yang merupakan bagian otak pusat pengaturan memori dan proses belajar. Penelitian ini bertujuan untuk menganalisis pengaruh ikan teri terhadap kemampuan spasial tikus usia satu bulan.

Metoda: Penelitian eksperimental murni dengan post test only with control group design yang diterapkan pada 21 tikus Sprague dawley usia satu bulan dengan random allocation sampling dalam 3 kelompok yaitu kontrol, kelompok pemberian ikan teri dan kelompok pemberian minyak ikan. Subjek diberikan diet dengan ikan teri sebanyak 1,5 gram per 200 gram berat badan dan minyak ikan sebanyak 167 mg per 200 gram berat badan yang dicampurkan ke pakan selama 14 hari. Pengujian kemampuan spasial menggunakan uji Morris Water Maze yang akan mengukur tingkat kemampuan observasi spasial dan spasial bias subjek. Data dianalisis dengan nonparametik Wilcoxon dan Multivariate ANOVA yang dilanjutkan dengan uji LSD pada tingkat kepercayaan 95\%.

Hasil: Terdapat perbedaan persen penurunan waktu pencarian landasan yang nyata pada kelompok pemberian ikan teri yaitu penurunan sebesar $67.89 \%$ dibandingkan dengan kelompok kontrol (21.53\%) namun tidak berbeda nyata dengan kelompok minyak ikan. Terdapat perbedaan pada tingkat spasial bias antar kelompok namun tidak terbukti signifikan secara statistika.

Kesimpulan: Pemberian diet dengan ikan teri (Engraulis encrasicolus) meningkatkan kemampuan observasi spasial namun tidak menurunkan tingkat spasial bias pada anak tikus sehat.

Kata kunci : Engraulis encrasicolus; memori spasial ; hipokampus; kognitif; morris water maze

\section{PENDAHULUAN}

Perkembangan kognitif pada anak dipengaruhi oleh banyak faktor, tiga faktor utama diantaranya adalah asupan zat gizi, genetik dan juga lingkungan ${ }^{1}$. Selain kecukupan energi, asamasam lemak omega-3 seperti EPA (Eicosapentaenoic Acid) dan DHA (Docosahexaenoic Acid) merupakan zat gizi makro yang harus diperhatikan kecukupannya selama proses tumbuh kembang anak.

Perkembangan otak pada anak mencapai masa-masa tercepat pada beberapa fase, yaitu fase pertama pada usia 2 tahun, fase kedua pada usia 7 9 tahun dan terakhir pada pertengahan masa remaja ${ }^{2}$. Pada rodensia, masa penyapihan beakhir pada hari ke 21 sedangkan pada manusia pada usia 6 bulan. Pada rodensia akan memasuki masa

\footnotetext{
${ }^{*}$ Penulis Penanggungjawab
} 
pubertas pada hari ke 40 hingga 60 sedangkan pada manusia berkisar pada 8-16 tahun. Rentang usia 79 tahun yang merupakan fase kedua perkembangan tercepat otak manusia, maka usia hewan uji yang digunakan ditetapkan berada antara rentang 21 dan 40 hari dan diputuskan menggunakan tikus dengan usia 30 hari atau satu bulan ${ }^{3}$.

Asam lemak omega-3 berperan penting dalam perkembangan otak dengan meningkatkan ekspresi gen-gen faktor transkripsi pada sel-sel hipokampus. Tingkat konsumsi omega-3 terutama EPA dan DHA yang adekuat merupakan faktor yang sangat penting pada fungsi otak dan meningkatkan ekspresi gen PPARs ${ }^{4}$. Defisiensi omega-3 pada jaringan otak terbukti dapat menurunkan kemampuan kognitif dan gangguan kognitif sedang (Mild Cognitive Impairment) ${ }^{5}$.

Asupan makanan memiliki kandungan asam lemak omega- 6 yang relatif banyak namun defisien terhadap asam lemak omega- $3^{4}$. Asam lemak omega-3 sebaiknya dipenuhi dari konsumsi bahan pangan sumber omega-3.Salah satu jenis asam lemak omega-3 yang sulit terpenuhi kebutuhannya adalah EPA dan DHA. EPA dan DHA bersumber dari produk perikanan laut dalam seperti salmon dan makarel dengan harga yang mahal dan sulit didapatkan. Penggunaan suplemen omega-3 seperti minyak ikan masih menjadi cara pemenuhan utama kebutuhan asam lemak omega-3 khususnya EPA dan DHA. Meski demikian, penggunaan suplementasi sebagai cara pemenuhan kebutuhan sampai saat ini masih menuai kontroversi dan tidak dianjurkan penggunaannya kecuali untuk penanganan defisiensi berat ${ }^{6}$. Selain itu, harga yang mahal membuat suplemen omega-3 tidak dapat dijangkau oleh semua kalangan ekonomi sehingga pemenuhan asupan omega-3 masih sulit dipenuhi.

Ikan teri (Engraulis encrasicolus) merupakan produk perikanan lokal yang murah dan sangat mudah ditemukan. Ikan teri yang termasuk kedalam golongan oily-fish memiliki kandungan asam lemak omega-3 yang tergolong tinggi yaitu $14 \mathrm{mg}$ per gram bahan dengan komposisi 5 mg EPA dan 9 mg DHA ${ }^{7}$. Meskipun analisis kandungan omega-3 pada ikan teri (Engraulis encrasicolus) menunjukan kadar yang tinggi, penggunaannya sebagai sumber alternatif asam lemak omega-3 masih jarang dilakukan. Sebuah studi menunjukan bahwa pemberian suplemen Alga-DHA sebanyak $900 \mathrm{mg}$ selama enam bulan dapat meningkatkan kemampuan belajar dan fungsi memori pada lansia sehat ${ }^{8}$. Studi lain menunjukan pemberian suplementasi DHA dosis sedang $400 \mathrm{mg}$ perhari dan dosis tinggi 1200 mg perhari selama 8 minggu pada anak laki-laki sehat 8-10 tahun menunjukan peningkatan komposisi DHA membran eritrosit yang berkorelasi positif dengan peningkatan peningkatan kemampuan kognitif ${ }^{9}$. Kajian mengenai pengaruh pemberian omega-3 dari bahan pangan seperti ikan teri (Engraulis encrasicolus) dengan kemampuan kognitif terutama memori spasial belum pernah dikaji.

Morris water maze testmerupakan model eksperimen yang sudah sejak lama digunakan dalam pengujian kemampuan kognitif dan memori pada hewan uji. Rangkaian tes didalam uji ini terbukti dapat menggambarkan kinerja memori spasial hewan uji dengan membuat hewan uji mendayagunakan otak bagian hipokampus dengan memberikan tes yang memerlukan penggunaan asosiasi elemental dan juga asosiasi konfigural kompleks dari hewan untuk menyelesaikannya ${ }^{10}$.

Rattus novergicus strain Sprague dawley atau tikus rumah merupakan salah satu hewan yang sering digunakan dalam penelitian penyakit dan kesehatan, termasuk penelitian kognitif seperti pengujian memori spasial. Kemiripan genetika antara tikus dengan manusia, tingkat adaptasi terhadap uji yang diberikan merupakan alasan utama pemilihan tikus Sprague dawley untuk digunakan dalam pengujian preklinis.

\section{METODE \\ Subjek Penelitian}

Subjek yang digunakan pada penelitian ini adalah tikus Sprague dawley berusia satu bulandengan berat badan 40-65 gram yang diperoleh dari LPPT UGM UNIT IV (Unit Pengembangan Hewan Percobaan), Universitas Gadjah Mada Yogyakarta. Pemeliharaan hewan coba dan uji akhir Morris Water Maze dilakukan di LPPT UGM UNIT IV.

\section{Bahan}

Bahan yang digunakan selama penelitian berlangsung meliputi pakan standar, ikan teri (Engraulis encrasicolus), minyak ikan, bahan pewarna non toksik (susu cair) untuk uji MWM. Pakan standar yang digunakan adalah jenis BR 2 (Broiler Finisher) Comfeed denganaquades.

\section{Metode Penelitian}

Penelitian ini menggunakan rancangan true experiment dengan post test only with control group design. Pemilihan subjek penelitian untuk pengelompokan dan perlakuan yang diberikan menggunakan random allocation sampling. Variabel bebas adalah pemberian ikan teri, sedangkan variabel terikat adalah waktu pencarian (Escape latency) dan waktu observasi (probe time) 
tikus dari uji spasial memori Morris water maze. Subjek penelitian dibagi menjadi 3 kelompok dengan keterangan sebagai berikut

$\mathrm{K}+\quad$ : Kelompok kontrol positif diberi pakan standar dengan minyak ikan.

K- : Kelompok kontrol negatif pakan standar tanpa penambahan apapun.

$\mathrm{P}:$ Kelompok perlakuan pakan dengan penambahan ikan teri.

Setiap kelompok memiliki jumlah subjek yang dihitung menggunakan rumus besar subjek standar WHO untuk pengujian preklinis yaitu 5 ekor. Kemudian jumlah sampel masing-masing kelompok ditambahkan $25 \%$ drop out sampel untuk antisipasi apabila terdapat tikus yang mati selama adaptasi maupun perlakuan yaitu 1.25 ekor atau 2 ekor. Jadi jumlah subjek tiap kelompok perlakuan adalah 7 ekor dan jumlah sampel keseluruhan adalah 21 ekor.

\section{Tahapan Penelitian}

Penelitian dilaksanakan dalam beberapa tahap yang dapat dilihat dalam gambar berikut ini

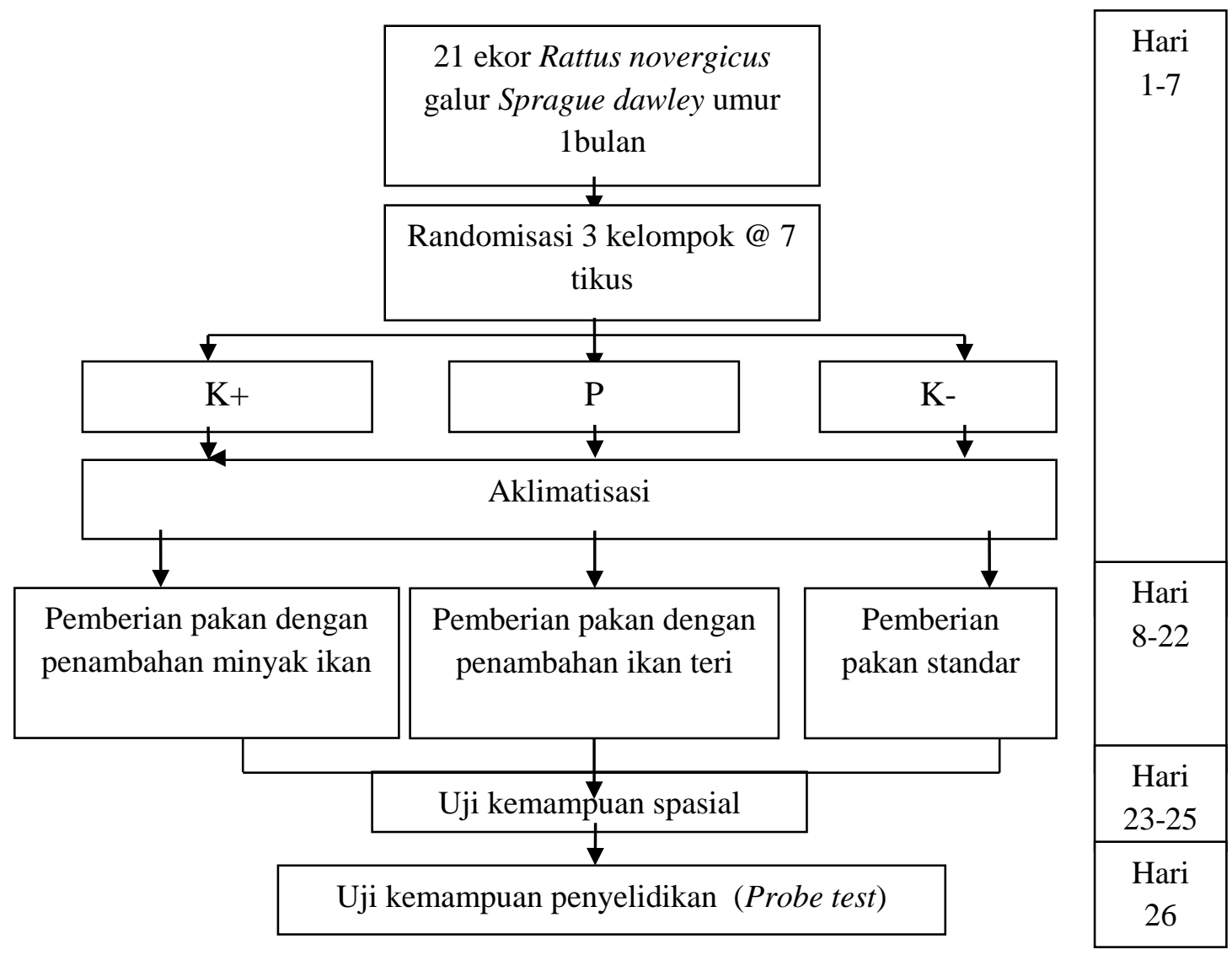

\section{Gambar 1. Bagan Alur Kerja Penelitian}

Seluruh subjek penelitian dipelihara di kandang individual dan diberi pakan standar serta air minum ad libitum. Masing-masing subjek sudah dikelompokkan sebelum aklimatisasi. Aklimatisasi dilakukan selama 7 hari.Selanjutnya subjek diberikan variasi makanan yaitu pakan standar untuk kelompok kontrol negatif (K-), pakan dengan penambahan ikan teri pada kelompok perlakuan (P) dan pakan dengan penambahan minyak ikan untuk kelompok kontrol positif $(\mathrm{K}+)$ selama 14 hari masa intervensi.

Penambahan ikan teri dan minyak ikan dilakukan dengan mempertimbangkan kandungan asam lemak omega-3 dari masing-masing bahan. Dosis omega-3 yang diberikan ditetapkan berdasar beberapa studi terdahulu yang menunjukan tingkat pemberian omega-3 terhadap perkembangan kognitif dan memori berkisar pada 400-1200 mg omega-3 perhari.Penentuan dosis hewan dilakukan dengan menggunakan rumus FDA (Foods and Drugs Association) dan didapatkan dosis hewan yaitu $20 \mathrm{mg} / 200$ gram berat badan ${ }^{11}$. Jumlah ikan teri dan minyak ikan yang diberikan didasarkan pada dosis omega-3 yang telah dihitung yaitu 20 mg Omega-3 / 200 gr BB. Pada setiap 1 gram bahan ikan teri terdapat $14 \mathrm{mg}$ omega-3 maka jumlah ikan teri yang diberikan adalah 1,5 gram/200 gr BB atau 1,5 gram per 10 gr pakan. Minyak ikan mengandung $\pm 12 \%$ omega- $3^{12}$ maka 
diperlukan $167 \mathrm{mg}$ minyak ikan per 10 gram pakan atau $167 \mathrm{mg}$ minyak ikan/200 gram BB.

Tabel1. komposisi ikan teri per 100 gram bahan ${ }^{7,13}$

\begin{tabular}{lc}
\hline \multicolumn{1}{c}{ Zat gizi } & Jumlah \\
\hline Kalori (kkal) & 156 \\
Protein (gram) & 9.3 \\
Lemak total (gram) & 11 \\
Lemak Jenuh (gram) & 3.5 \\
Kolesterol (mg) & 64.2 \\
EPA (g) & 0.5 \\
DHA (g) & 0.9 \\
Karbohidrat total (gram) & 4.6 \\
Gula (gram) & 2 \\
Serat pangan (gram) & 0.5 \\
Natrium (mg) & 242 \\
Kalium(mg) & 345 \\
\hline
\end{tabular}

Setelah masa intervensi, hewan uji dipersiapkan untuk melakukan uji Morris Water Maze. Uji Morris Water Maze digunakan menggunakan kolam plastik bulat dengan diameter $100 \mathrm{~cm}$ dan tinggi $30 \mathrm{~cm}$. Kolam diisi dengan air hingga ketinggian $15 \mathrm{~cm}$ dan landasan diletakan pada salah satu kuadran. Petunjuk visual diletakan diluar kolam di sisi masing-masing titik masuk dan diletakan pada jarak jangkauan penglihatan tikus.

Pengujian kemampuan spasial dilakukan selama 3 hari dan dilanjutkan dengan pengujian kemampuan observasi 24 jam setelahnya. Uji kemampuan spasial dilakukan sebanyak 6 sesi selama 3 hari, dengan 2 sesi setiap harinya dan masing-masing sesi dilakukan 4 pengulangan. Penentuan titik masuk dibagi secara semi-acak dimana pada sesi ganjil, ulangan pertama akan dilakukan pada titik masuk 1 dan selanjutnya dilakukan berurut searah jarum jam (1-2-3-4). Ulangan pertama pada sesi genap dilakukan pada titik masuk 4 dan akan berurut berlawanan arah jarum jam (4-3-2-1). Pembagian dengan metode tersebut ditujukan untuk mengukur tingkat fokus jangka pendek hewan uji dan tingkat observasi spasial dengan menggunakan tidak hanya satu petunjuk visual. Pengukuran dilakukan menggunakan alat bantu berupa stopwatch. Hewan uji diberikan waktu maksimal 60 detik pada masing-masing ulangan untuk menemukan landasan tersembunyi. Perhitungan waktu dihentikan saat hewan uji berhasil menemukan landasan dan berdiri selama 2 detik diatasnya. Apabila waktu yang diberikan sudah habis tetapi hewan uji belum berhasil menemukan landasan, maka hewan uji akan diarahkan langsung ke landasan dan diletakan diatasnya selama 20 detik. Setelah satu ulangan selesai, hewan uji dikeringkan untuk mencegah hipotermi dan diberikan waktu istirahat selama 35 detik. Setelah waktu jeda habis, hewan uji memasuki ulangan selanjutnya. Setelah empat kali ulangan diselesaikan, hewan uji dijemur dan diistirahatkan selama 1 jam sebelum memasuki sesi genap.

Uji kemampuan observasi (Probe test) dilakukan 24 jam setelah ulangan terakhir dari uji kemampuan spasial dilaksanakan. Probe test dilakukan dengan mengambil landasan dari tempatnya. Probe test dilakukan satu sesi dengan empat ulangan dengan pelepasan dimulai dari titik masuk pertama dan berurut searah jarum jam (1-23-4). Perhitungan dilakukan setiap kali hewan uji memasuki kuadran tempat landasan diletakan sebelumnya. 


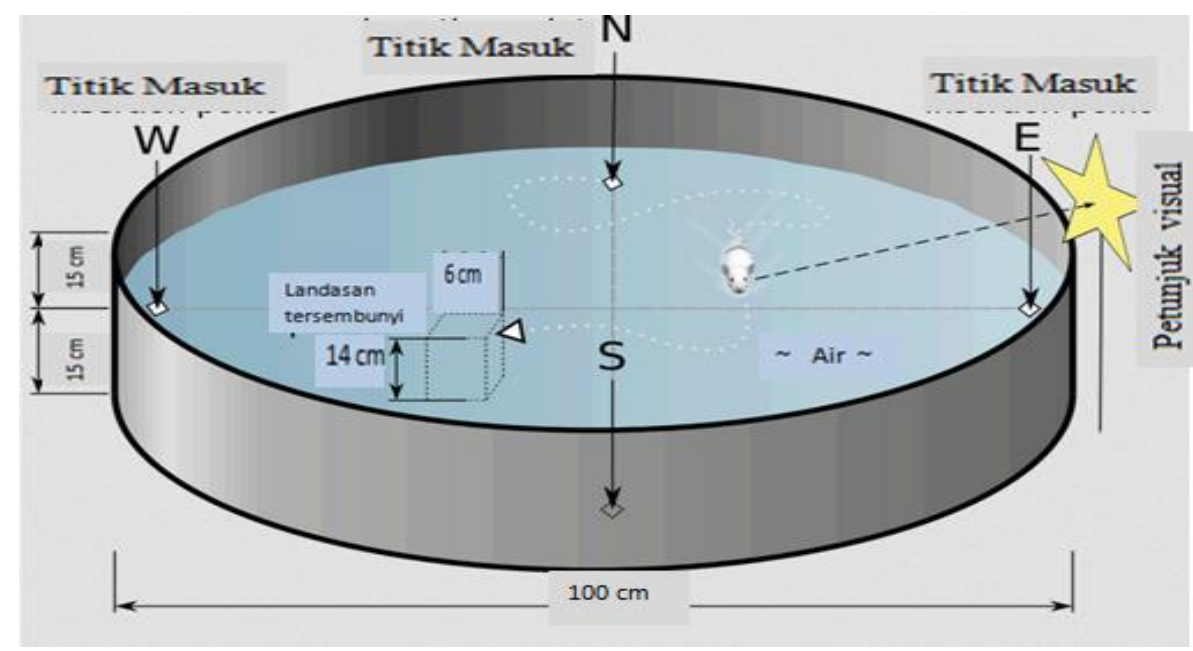

Gambar 2. Ilustrasi Kondisi Pengujian Morris Water Maze

\section{Analisis Data}

Seluruh data yang terkumpul dianalisis secara statistik menggunakan program komputer SPSS 16. Data tersebut diuji normalitasnya menggunakan uji Saphiro-Wilk. Kemudian dilakukan uji beda non-parametrik Wilcoxonpada waktu uji hari pertama dengan waktu uji hari terakhir. Perbedaan waktu uji hari pertama, hari kedua, hari ketiga, lama waktu observasi probe test dan persentase penurunan waktu uji antar kelompok sampel diuji menggunakan MultivariateANOVA yang dilanjutkan dengan uji LSD (Least
Significant Difference). Semua uji dilakukan menggunakan tingkat kepercayaan $95 \%$.

\section{HASIL}

Kemampuan Performa Observasi Spasial Uji Landasan Tersembunyi Morris Water Maze

Kemampuan spasial yang didapatkan dari pengukuran uji landasan tersembunyi pada Morris Water Maze Test berupa tingkat performa observasi spasial hari 1-3 yang ditunjukan pada Gambar 3

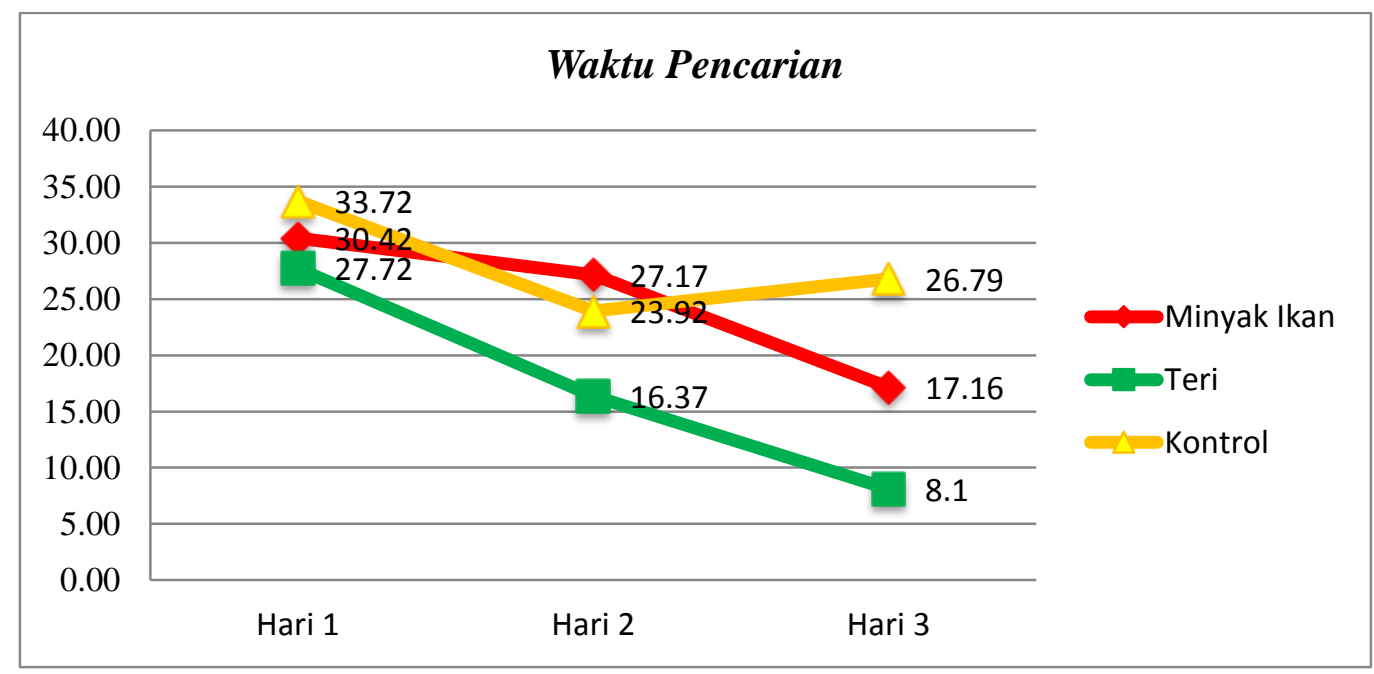

Gambar 3. Grafik Perkembangan Waktu Pencarian Antar Kelompok

Gambar 3. menunjukan bahwa terdapat pada hampir semua kelompok dari hari penurunan lama waktu pencarian landasan pertama sampai hari ketiga. 
Tabel 2. Rata-Rata Waktu Harian Uji Kemampuan Spasial Antar Kelompok

\begin{tabular}{lllll}
\hline Kelompok & $\begin{array}{l}\text { Hari 1 } \\
(\text { detik })\end{array}$ & $\begin{array}{l}\text { Hari 2 } \\
(\text { detik })\end{array}$ & $\begin{array}{l}\text { Hari 3 } \\
(\text { detik })\end{array}$ & $\begin{array}{l}\text { Tingkat Penurunan } \\
(\%)\end{array}$ \\
\hline Kontrol & 33,72 & 23,92 & 26,79 & 21,53 \\
Ikan teri & 27,72 & 16,37 & 8,10 & 67,89 \\
Minyak Ikan & 30,42 & 27,17 & 16,60 & 42,18 \\
\hline sig.* & & & & $0,023^{\circ}$ \\
*p MANOVA & ${ }^{\circ} \mathrm{p}<0,05$ & &
\end{tabular}

Tabel 2 menunjukan adanya perbedaan yang signifikan antar kelompok sampel pada tingkat penurunan waktu uji. Kelompok perlakuan diet dengan penambahan ikan teri mengalami penurunan waktu uji paling besar dari ketiga kelompok sampel dengan persentase penurunan sebesar $67.89 \%$. Kelompok diet dengan ikan teri berbeda nyata dengan kelompok kontrol yang mengalami penurunan sebesar $21.53 \%$ namun tidak berbeda nyata dengan kelompok pemberian diet dengan minyak ikan dengan penurunan sebesar 42.18\% (p: $0.023 ; \alpha: 0.05$ ). Data penurunan waktu uji masing-masing sesi tiap kelompok sampel dapat dilihat pada gambar 4 .
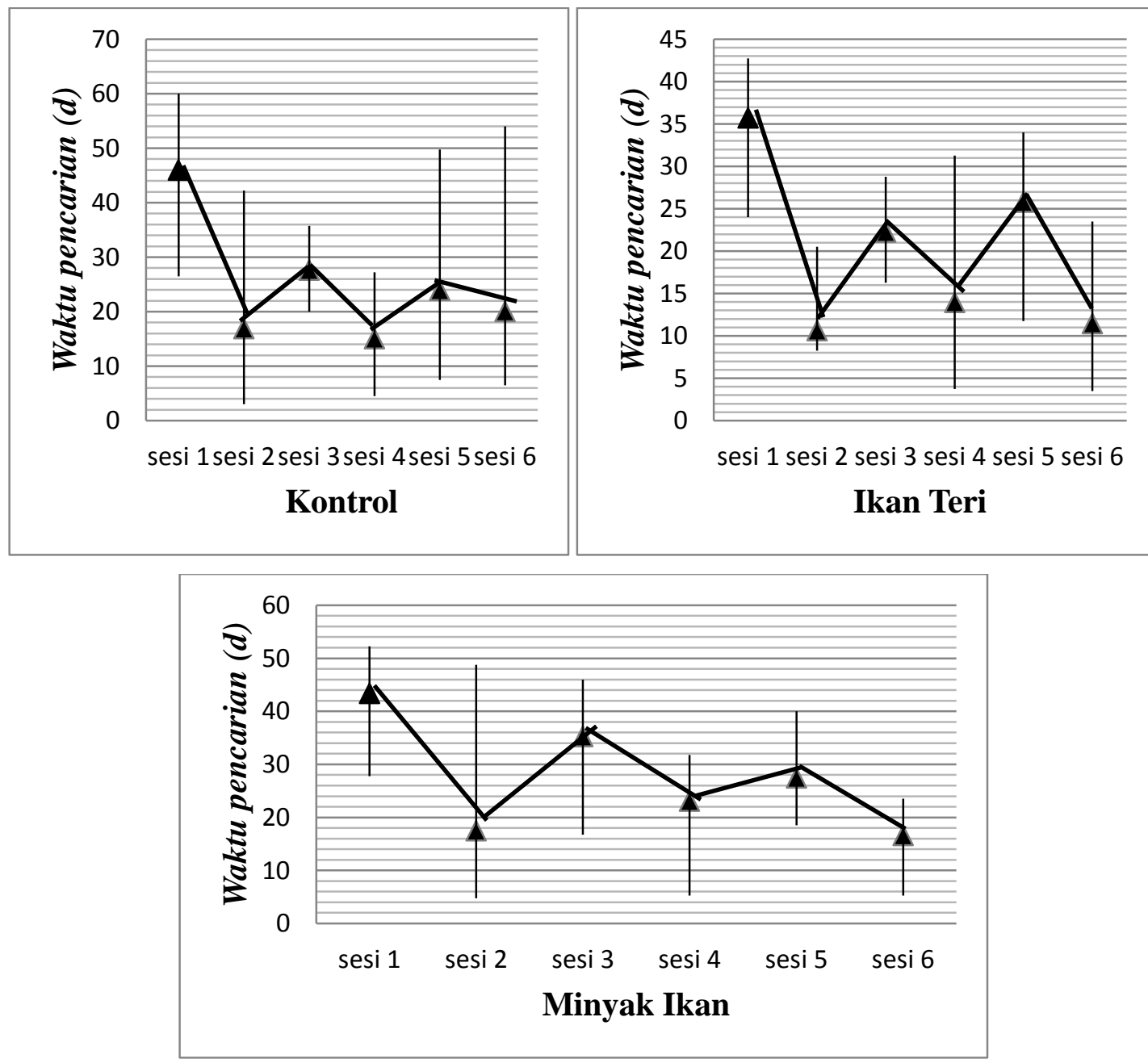

Gambar 4. Perubahan waktu pencarian antar sesi tiap kelompok sampel

Tingkat Spasial Bias Probe test Morris Water Maze
Data uji spasial bias Probe Test pada ketiga kelompok sampel dapat dilihat pada gambar 4. 


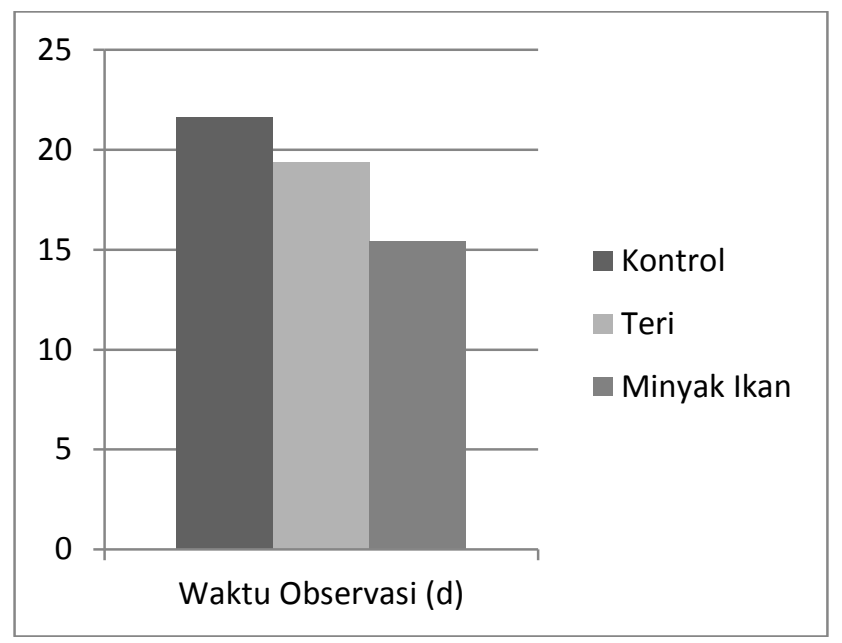

Gambar 5. Waktu Observasi Probe test antar kelompok sampel

Gambar 5. Menunjukan adanya perbedaan pada lama waktu observasi hewan uji pada probe test. Kelompok kontrol rata-rata menghabiskan waktu 21.65 detik untuk melakukan observasi, kelompok diet dengan ikan teri menghabiskan waktu 19.40 detik dan kelompok minyak ikan 15.45 detik. Meski terlihat terdapat perbedaan dari ketiga kelompok, perbedaan tersebut tidak terbukti secara statistik. Pada pengujian statistik tidak terdapat perbedaan yang nyata pada waktu observasi probe test pada semua kelompok sampel.

\section{PEMBAHASAN}

Tingkat Kemampuan Observasi Spasial dan Spasial Bias Morris Water Maze

Tabel 1 menunjukan adanya perbedaan kecepatan pencarian landasan antar kelompok sampel. Selain itu, terjadi penurunan waktu pencarian dari hari pertama uji ke hari terakhir. Kelompok perlakuan diet dengan penambahan ikan teri mengalami tingkat penurunan waktu uji lebih tinggi dibanding kelompok kontrol dan pemberian diet dengan minyak ikan. Hal tersebut mengindikasikan adanya perbedaan tingkat kemampuan observasi spasial pada subjek dalam kelompok diet penambahan ikan teri jika dibandingkan dengan kelompok kontrol dan minyak ikan.

Meskipun demikian, walaupun grafik pada Gambar 4. terlihat menunjukan adanya perbedaan pada tingkat spasial bias antar kelompok, hal tersebut tidak terbukti pada pengujian statistik yang mengindikasikan bahwa tidak ada perbedaan yang nyata pada akurasi proses belajar hewan uji.
Terjadinya perbedaan kemampuan observasi spasial pada kelompok ikan teri dipengaruhi oleh beberapa zat yang terkandung dalam ikan teri tersebut diantaranya asam lemak omega-3 dalam bentuk DHA dan EPA serta dietary protein.

Asam lemak dapat mengaktivasi dan menginduksi enzim pada jalur oksidasi $\beta$ peroksisomal yang merupakan katalis dalam proses pemotongan rantai-rantai ester asetil KoA dan menghasilkan asil KoA, asetil KoA dan Propionil $\mathrm{KoA}^{14}$. Asetil KoA memegang peranan dalam pengaturan sinaptoplasmik dari terminal persyarafan kolinergik yang mengatur sintesis asetilkolin ${ }^{15}$. Asetilkolin yang merupakan neurotransmitter berperan dalam proses belajar dan memori dengan cara meningkatkan laju proses LTP (Long-term Potentiation) pada beberapa bagian otak termasuk pada hipokampus ${ }^{16}$.

Selain itu, asam lemak Omega-3 dalam bentuk EPA dan DHA menstimulasi faktor transkripsi pada hipokampus yang akan mengatur tingkat plastisitas snaptik neuron otak, PPARs (Peroxisome Proliferator-Activated Receptors. PPARs merupakan messenger utama yang bertanggung jawab dalam proses translasi stimulan zat gizi sampai terjadinya perubahan ekspresi gen terutama gen-gen yang terkait proses metabolisme lipid dan sintesis asetilkolin ${ }^{2}$. PPAR- $\alpha$ berfungsi sebagai regulator pada biosintesis asetilkolin yang mempengaruhi fungsi kognitif. Sedangkan PPAR- $\gamma$ memiliki peran penting dalam regulasi inflamasi dan neuroproteksi sistem syaraf pusat yang dapat meningkatkan performa kognitif individu ${ }^{4}$. 


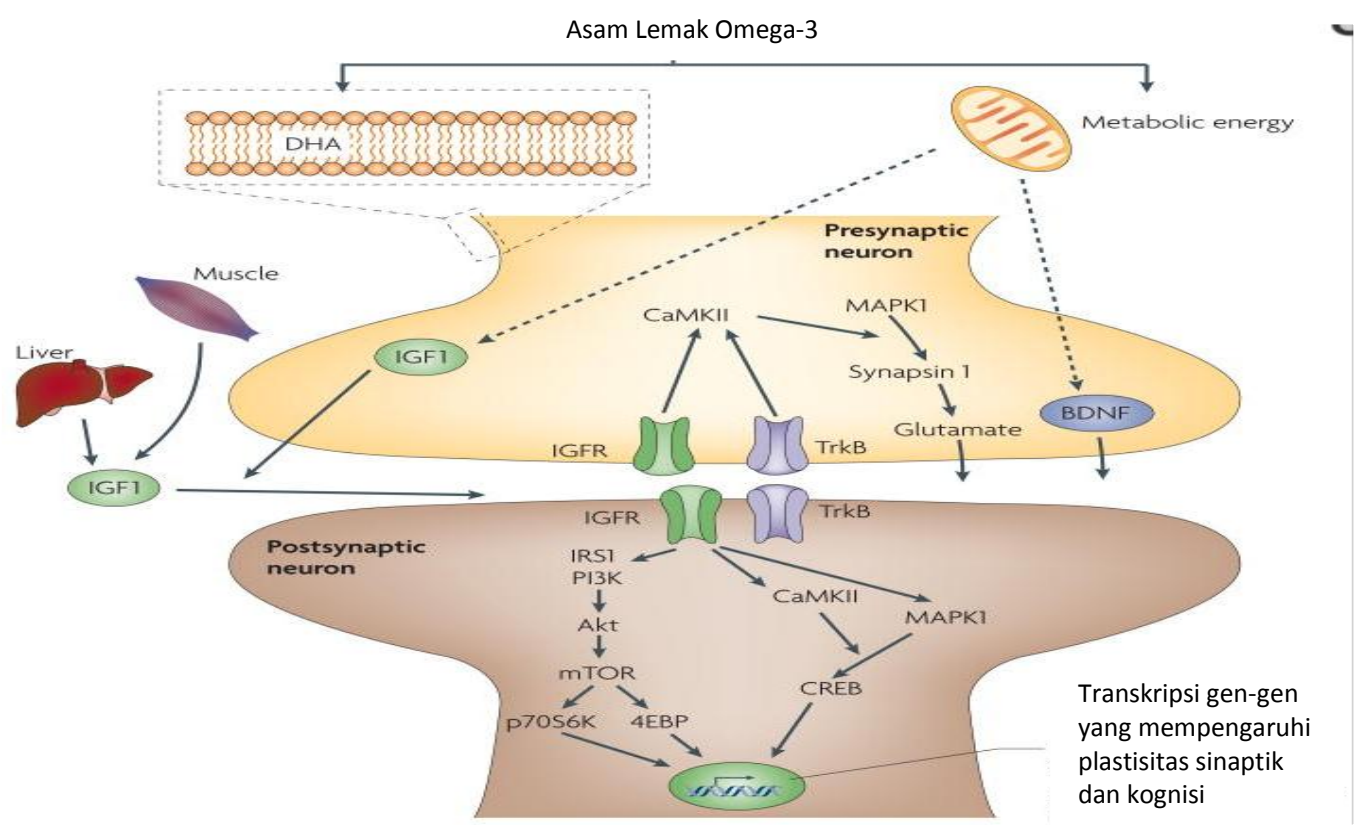

Gambar 5. Mekanisme Omega-3 terhadap Plastisitas Sinaptik dan Kognisi

\section{SIMPULAN}

Performa observasi spasial subjek yang diberi diet dengan komposisi $15 \%$ ikan teri berbeda signifikan lebih baik dibandingkan dengan subjek yang diberikan pakan standar maupun minyak ikan. Namun tidak terlihat adanya perbedaan yang signifikan pada tingkat spasial bias.

\section{SARAN}

Pemberian diet dengan penambahan ikan teri (Engraulis encrasicolus) dapat dilakukan studi lanjutan pada hewan uji dengan model gangguan kognitif seperti model gangguan kognitif seperti autisme, ADHD ataupun Downsyndrome karena penelitian pada penelitian pada hewan uji normal didapatkan hasil adanya perbedaan yang signifikan pada tingkat fokus observasi spasial hewan uji. Selain itu, penelitian menganai diet dengan penambahan ikan teri juga dapat dilanjutkan dengan menggunakan subjek manusia. Perlu dilakukan penelitian lanjutan mengenai efek pemberian ikan teri dan minyak ikan jangka panjang.

\section{DAFTAR PUSTAKA}

1. Anonim. Mealtime Memo for Child Care, Nutrition and Cognitive Development.National Food Service Management Institute The University of Mississippi [Internet]. Juli 2011 [disitasi pada 14 Maret 2014]. Dapat diakses http://www.nfsmi.org/documentlibraryfiles/PDF/200 80612091850.pdf
2. Kuratko CN, Barrett EC, Nelson EB, Norman Salem Jr. The Relationship of Docosahexaenoic Acid (DHA) with Learning and Behavior in Healthy Children: A Review. Nutrients. Jul 2013; 5(7): 2777-2810.

3. Sengupta Pallav. A Scientific Review of Age Determination for a Laboratory Rat: How Old is it in Comparison with Human Age? A review. Biomedicine International 2011; 2: 81-89.

4. Hajjar, Meng GY, Rajion MA, Vidyadaran Sharmili, Othman Fauziah, Farjam, et al. Omega 3 polyunsaturated fatty acid improves spatial learning and hippocampal Peroxisome Proliferator Activated Receptors (PPAR $\alpha$ and PPAR $\gamma$ ) gene expression in rats. BMC Neuroscience 2012, 13:109.

5. Kidd Parris M. Omega-3 DHA and EPA for Cognition, Behavior, and Mood: Clinical Findings and Structural- Functional Synergies with Cell Membrane Phospholipids.Altern Med Rev. 2007;12(3):207-227.

6. Howard LeWine. Harvard Health Publications [Internet].[Tempat tidak diketahui]; Harvard Medical School. Juli 2013. Dapat diakses di:http://www.health.harvard.edu/blog/fishoil-friendor-foe-201307126467

7. Nettleton JA. Omega-3 Fatty Acid and Health. Chapman \& Hall, 115 Fifth Ave., New York. 2003;NY 10003, PP.21-30.

8. Turner Julia. Your Brain on Food: A Nutrient-Rich Diet Can Protect Cognitive Health. Journal of the American Society on Aging. 2011; Vol. 35 .No. 2 99-106.

9. McNamara, R.K., Able, J., Jandacek, R., Rider, T., Tso, P., Eliassen, J.C., et al. Docosahexaenoic acid supplementation increases prefrontal cortex activation during sustained attention in healthy boys: a placebo-controlled, dose-ranging, functional 
magnetic resonance imaging study. 2010;Am. J. Clin. Nutr. 91, 1060e1067.

10. Anonim. Morris Water Maze - A Test of Behaviour. Department of Psychology and Neuroscience Colorado Unoversity Boulder Website. Dapat diakses di http://psych.colorado.edu

11. Shin Jang-Woo, Seol In-Chan, Son Chang-Gue. Interpretation of Animal Dose and Human Equivalent Dose for Drug Development. The Journal of Korean Oriental Medicine 2010;31(3)

12. Dewitt KW. Seasonal variations in cod liver oil. J. Sci Food Agr. 1963; 14,92-98.

13. Costa HS. New nutritional data on traditional foods for European food composition databases. European Journal of Clinical Nutrition. 2010; 64, S73-S81

14. Poirier Yves, Antonenkov VD, Glumoff T, Hiltunen JK. Peroxisomal $\beta$-oxidation-A metabolic pathway with multiple functions. Biochimica et Biophysica Acta 1763. 2006; 1413-1426.

15. Szutowicz Andrzej, Tomaszewicz M, Bielarczyk H. Disturbances of acetyl-CoA, energy and acetylcholine metabolism in some encephalopathies. Acta Neurobiol, Exp. 1996, 56: 323-339.

16. Hasselmo ME. The Role of Acetylcholine in Learning and Memory. Curr Opin Neurobiol 2006; 16(6): 710-715 